\title{
A BIOCHEMICAL STUDY OF CERTAIN SKELETAL MUSCLE CONSTITUENTS IN HUMAN PROGRESSIVE MUSCULAR DYSTROPHY *
}

\author{
By PAUL J. VIGNOS, JR. AND M. LEFKOWITZ
}

(From the Department of Medicine, Western Reserve University School of Medicine, Cleveland, Ohio)

(Submitted for publication June 8, 1956; accepted February 5, 1959)

Many biochemical studies on skeletal muscle have been reported in experimental muscular dystrophy of animals. The effect of vitamin $\mathrm{E}$ deficiency on muscle metabolism has been most intensively studied. The disease of animals which most closely resembles human muscular dystrophy by genetic and histologic criteria is the hereditary primary myopathy of the mouse (1).

This mutant muscle disease of the mouse provides a useful tool for research. However, the metabolic and etiologic correspondence with human muscular dystrophy is not yet established. It would appear, therefore, that it might be worthwhile to study muscular dystrophy in man by chemical analysis of muscle obtained at biopsy from patients with this disease.

This report describes some biochemical studies on the skeletal muscles of patients with progressive muscular dystrophy. This disease is of particular interest because it is the most frequently occurring primary myopathy and may be regarded as the prototype of primary degenerative muscle disease. Skeletal muscle secondarily atrophic due to neurogenic disease of the lower motor neuron has been studied to determine whether biochemical changes in dystrophic muscle are due to nonspecific effects of muscle wasting. Diagnosis in all patients was based on combined clinical and histologic findings. Clinically, all the dystrophy patients were ambulatory and in the early stages of the disease by functional classification and extent of muscle involvement. It was hoped that any characteristic biochemical alterations might be better appreciated in the muscles of early disease rather than in the replaced and scarred tissue of advanced disease. In the latter case, similar end stage changes may be seen in any type of chronic myopathy.

* This work has been supported by a grant from the Muscular Dystrophy Association of America, Inc.

\section{METHODS}

The study was done on skeletal muscle obtained by surgical biopsy. Muscle was excised under general anesthesia in both patients and controls. One type of general anesthesia, cyclopropane, was used in all patients in order to reduce one potential source of experimental variation. Normal control muscle samples were secured from individuals with no clinical evidence of muscle weakness. The muscle was normal by histologic examination. This group was composed of seven females and three males varying in age between 2 and 47, with a median age of 30 . A second group of controls had muscle disease secondary to neurogenic causes. Muscular dystrophy patients studied were ambulatory for the purpose of diminishing the factor of nonspecific disuse atrophy.

There is no universal agreement on classification in progressive muscular dystrophy. Indeed the classification of muscular dystrophy has been the source of dispute for many years (2). The clinical picture, in all 17 of the muscular dystrophy cases in this study, corresponds best with the classification of so-called "childhood type" of dystrophy described by Tyler and Stephens (3).

On the basis of the experimental biochemical data, the 17 subjects with childhood type muscular dystrophy are divided into two groups. These two groups appeared to have different metabolic patterns on the basis of the biochemical studies of muscle. The separation of the dystrophy cases into two categories has been done for the purpose of better handling of the experimental results. It is not the intention of this paper to offer still another classification of dystrophy. The clinical differences between the two groups of muscular dystrophy patients in this paper were in the age at onset of muscle weakness and the age at time of muscle biopsy. The 17 cases of muscular dystrophy were divided by these age criteria into two arbitrary groups. Those under the age of 20 , at time of surgical muscle biopsy, are termed juvenile dystrophy, while those over 20 years of age at this time are called adult dystrophy. These two patient groups are further differentiated by the age when muscle weakness was first noted. The group termed juvenile dystrophy had muscle weakness beginning before the age of six years, while the so-called adult dystrophy patients' symptoms began after the age of six.

Symptoms of muscle weakness in both groups were first noted in activities involving the muscles of the pelvic girdle. No patient had the first symptoms referrable to 
the muscles of the pectoral girdle. It is recognized that the history of initial muscle involvement may be misleading, but the pattern of muscle weakness in no case indicated a disproportionate early or severe involvement of the pectoral girdle or facial muscles, as is seen in the facioscapulohumeral type of dystrophy.

The pattern of muscle involvement, joint contractures and family history were similar in the two groups of muscular dystrophy. Contractures seem to be largely secondary to muscle imbalance and were present in all cases (4). There is only an occasional patient with a family history of muscle weakness. All cases showed progression of muscle weakness and there was no plateau in any patient as may be seen in polymyositis.

The pattern of individual muscle weakness was determined by manual muscle tests. All biopsied muscles used in this study were examined histologically to rule out causes of weakness other than these diagnosed on clinical grounds.

No method of grading muscle capacity in muscular dystrophy is completely satisfactory. However, since the pattern of muscle weakness in dystrophy is genetically determined, a functional classification gives worthwhile assistance in overall evaluation of the patients. This type of classification, although helpful, is less satisfactory in grading neurogenic myopathy due to the greater diversity of disease patterns. Patients are rated on a 10 point scale of functional ability based on performance of ambulation and elevation activities and on performance of activities of daily living. This is modified from the eight point scale of Swinyard, Deaver and Greenspan (5). The following criteria are used in functional classification.

1. Walks and climbs stairs without assistance.

2. Walks and climbs stairs with aid of railing.

3. Walks and climbs stairs slowly with aid of railing (over 25 seconds for eight standard steps).

4. Walks but cannot climb stairs.

5. Walks unassisted but cannot climb stairs or get out of chair.

6. Walks only with assistance or with braces.

7. In wheel chair; sits erect; can roll chair and perform bed and wheel chair activities without assistance.

8. In wheel chair; sits erect; unable to perform bed and chair activities without assistance.

9. In wheel chair; sits erect only with support; able to do only minimal activities of daily living.

10. In bed; can do no activities of daily living without assistance.

A second clinical method of assessing muscle strength was based on standard methods of manual muscle testing. To eliminate individual grading variations among different therapists, the same physical therapist did all the muscle testing in this report. Each muscle or muscle group was graded on a quantitative scale ranging from "zero" (no contraction) to "normal." This grade was then transposed to a numerical scale with zero as the lowest (no contraction) and 10 as the highest (normal) values. In order to arrive at a figure that would indi- cate the relative mass as well as the strength of the muscles, the numerical value was then multiplied by a factor rating ranging from one to four. The tibialis anterior muscle was selected as the muscle representing the standard of one. This factor rating is considered to remain relatively constant even with generalized atrophy. The above method was adapted from the work done to standardize muscle testing and evaluate function of the early poliomyelitis patient in relation to gamma globulin and polio vaccine trials (6). Although a complete and comprehensive muscle evaluation was done by the physical therapist, for the purposes of this study, the quantitative comparison was limited to 22 major muscles of the trunk and extremities which were considered to be a representative sampling of the muscle involvement. On this basis, a total score of 700 is the maximum that could be achieved by an individual who was rated "normal" for each muscle tested.

Muscle biopsies were taken from the rectus abdominis muscle in all controls and dystrophy patients. In three neurogenic atrophy patients this site was not considered suitable because of clinical considerations. This muscle was selected since it is involved early and uniformly in the course of childhood type muscular dystrophy and is easily obtainable from normal controls at laparotomy (3). All determinations were done in duplicate. Enzyme assays were done in duplicate and at two enzyme concentrations as a check on the linearity of the assay. Muscle specimens were wrapped in parafilm immediately after excision to prevent change in water content and immediately chilled in ice. Preparation of the muscle sample for analysis was begun within 10 minutes after removal of muscle at operation. The muscle was minced into a homogenous mash in the cold room at $4^{\circ} \mathrm{C}$. The muscle mash was divided into samples of appropriate size for the determinations and wrapped in parafilm to form an air-tight package. Each sample was rapidly weighed on a Roller-Smith Torsion Balance.

Myosin extraction was begun immediately after weighing. Myosin was extracted according to the Hasselbach and Schneider (7) modification of the classic myosin extraction technique. Extraction was done in the cold $\left(4^{\circ} \mathrm{C}\right.$.) using two periods of one hour each. Collagen was determined by the method of Lowry, Gilligan and Katersky (8). Nitrogen determinations were done by a semimicro-Kjeldahl method. Water content was determined after drying for 48 hours at $105^{\circ}$. Fat analysis was carried out on muscle mash samples by extraction with a 2 to 1 chloroform to methanol $(v / v)$ mixture according to the method of Folch and associates $(9,10)$.

In a comparative study of diseased and normal muscle, a parenchymal reference base must be used (11). The use of an adequate tissue reference base enables the investigator to determine net quantities of tissue constituents without the error introduced by varying quantities of nonfunctional fibrous tissue, extracellular water and fat. The tissue reference base used in this study has been noncollagenous nitrogen (12).

Muscle was prepared for enzyme assays in a Potter 
Elvehjem homogenizer at $4^{\circ} \mathrm{C}$. The homogenizing fluid was $0.12 \mathrm{M} \mathrm{KCL}$ and $0.00016 \mathrm{M} \mathrm{KHCO}_{3}$ at $\mathrm{pH}$ 7.0. A 1 to 10 homogenate was prepared. This homogenate was used for the succinic dehydrogenase assay performed by the method of Schneider and Potter (13). Creatine kinase activity was determined on the supernatant obtained by centrifugation of the original homogenate at $4^{\circ}$ at 6,500 $\times \mathrm{G}$. The term creatine kinase is used to describe the enzyme which phosphorylates creatine in the presence of adenosin triphosphate (ATP) to form creatine phosphate. The reaction mixture previously described (14) has been used with addition of fluoride to inhibit residual ATP-ase activity. The creatine phosphate formed by action of the enzyme creatine kinase can be determined as "apparent orthophosphate" since, as is well known, creatine phosphate is very labile at acid $\mathrm{pH}$ and is completely hydrolyzed to orthophosphate and creatine during the course of procedure used for phosphorus determination. Any orthophosphate not derived from creatine phosphate is corrected for by use of control determinations having the complete reaction mixture except for creatine. Calcium activated adenosine triphosphatase activity was determined on an aqueous dilution of the original homogenate according to the method of Dubois and Potter (15).

Overall glycolysis was tested in the homogenate using

TABLE I

Clinical data in disease groups studied

\begin{tabular}{|c|c|c|c|c|c|}
\hline Subject & Sex & Age & $\begin{array}{l}\text { Age at } \\
\text { onset of } \\
\text { disease }\end{array}$ & $\begin{array}{l}\text { Func- } \\
\text { tional } \\
\text { grade }\end{array}$ & $\begin{array}{c}\text { Total } \\
\text { muscle } \\
\text { score }\end{array}$ \\
\hline
\end{tabular}

A. Muscular dystrophy patients under 20 years of age

$\begin{array}{rrrrrr}1 & \text { M } & 5 & 1 & 1 & 607 \\ 2 & \text { M } & 6 & 3 & 2 & 537 \\ 3 & \text { M } & 6 & 3 & 1 & 506 \\ 4 & \text { M } & 5 & 4 & 2 & 472 \\ 5 & \text { M } & 7 & 3 & 1 & 426 \\ 6 & \text { M } & 6 & 4 & 2 & 383 \\ 7 & \text { M } & 5 & 3 & 2 & 342 \\ 8 & \text { M } & 9 & 4 & 6 & 338 \\ 9 & \text { M } & 6 & 2 & 3 & 336 \\ 10 & \text { M } & 16 & 3 & 3 & 316 \\ 11 & \text { M } & 8 & 5 & 4 & 245 \\ 12 & \text { M } & 10 & 4 & 4 & 175\end{array}$

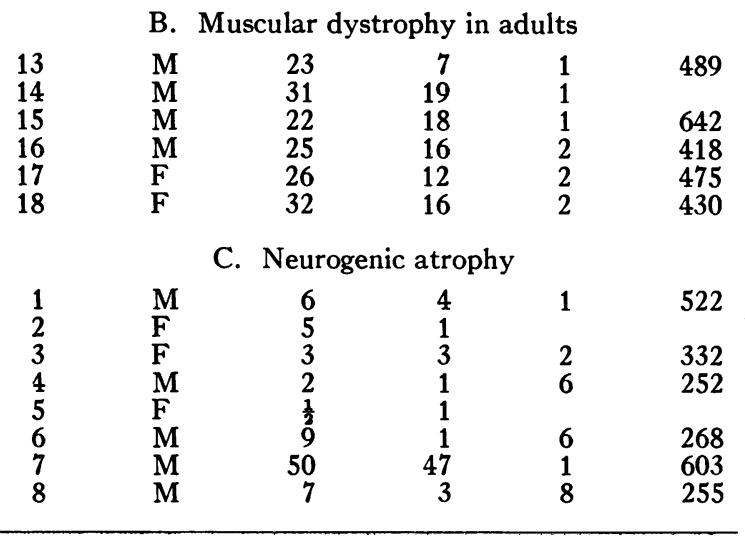

a modification of the system described by LePage (16). The complete system contained phosphate buffer, $0.03 \mathrm{M}$; nicotinamide, 0.0038 ; pyruvate, 0.002 . The incubation time was 15 minutes at $37^{\circ}$. The results are expressed as $\mu \mathrm{g}$. of lactic acid formed per $\mathrm{ml}$. of enzyme preparation.

\section{RESULTS}

Clinical data on patients with muscular dystrophy and neurogenic atrophy are shown in Table I. Data in the table are arranged, in general, according to the severity of the disease at time of biopsy. The three patient groups show a similar total muscle mass.

The degeneration of muscle in progressive myopathy is associated with the appearance of connective tissue and fat cells. At histologic examination, the muscle of early dystrophy is said to show more adipose tissue than does the muscle affected by neural atrophy (17). However, no quantitative studies of the fat content of human dystrophic muscle have been performed. The muscle fat, expressed as per cent of wet weight, was increased slightly in the muscles of patients with muscular dystrophy over its content in normal control muscle (Table II). However, the increase in muscle lipid was not statistically significant. The muscle of patients with neurogenic atrophy had a similar minimal nonsignificant increase in fat content.

Fibrosis with consequent replacement of muscle by connective tissue is another result of muscle degeneration. Collagen nitrogen, expressed as per cent of total nitrogen, was significantly elevated in both juvenile dystrophy and neurogenic atrophy compared with normal controls. Three of the adult dystrophics had a definite increase in muscle collagen and there was an overall increase in this group at the 0.05 level of significance. The increase in collagen content in the juvenile dystrophic and neurogenic atrophy patients represents a proportionately greater increase in connective tissue than in fat. There was a fair correlation between the collagen content of diseased muscle and the clinical status measured by either total muscle strength or functional classification.

The water content in normal control muscle agrees with the values of Barnes, Gordon and Cope (18). Water content of muscle in all patient groups was always slightly less than average water content of muscle from normal control subjects (Table II). Juvenile dystrophy showed 
TABLE II

Muscle fat, collagen and water content

\begin{tabular}{|c|c|c|c|c|c|c|c|c|c|}
\hline \multirow[b]{2}{*}{ Subject } & \multicolumn{3}{|c|}{$\begin{array}{l}\text { Fat } \\
\text { as } \% \text { of wet weight }\end{array}$} & \multicolumn{3}{|c|}{$\begin{array}{c}\text { Collagen } \\
\text { collagen } N \text { as } \\
\% \text { of total } N\end{array}$} & \multicolumn{3}{|c|}{$\begin{array}{c}\text { Water } \\
\text { as \% of wet weight }\end{array}$} \\
\hline & $\begin{array}{l}\text { Normal } \\
\text { controls }\end{array}$ & $\begin{array}{c}\text { Juvenile } \\
\text { dystrophy }\end{array}$ & $\begin{array}{l}\text { Neurog. } \\
\text { atrophy }\end{array}$ & $\begin{array}{l}\text { Normal } \\
\text { controls }\end{array}$ & $\begin{array}{l}\text { Juvenile } \\
\text { dystrophy }\end{array}$ & $\begin{array}{l}\text { Neurog. } \\
\text { atrophy }\end{array}$ & $\begin{array}{l}\text { Normal } \\
\text { controls }\end{array}$ & $\begin{array}{c}\text { Juvenile } \\
\text { dystrophy }\end{array}$ & $\begin{array}{l}\text { Neurog. } \\
\text { atrophy }\end{array}$ \\
\hline $\begin{array}{r}n o . \\
1 \\
2 \\
3 \\
4 \\
5 \\
6 \\
7 \\
8 \\
9 \\
10 \\
11 \\
12\end{array}$ & $\begin{array}{l}1.42 \\
2.06 \\
2.90 \\
2.51 \\
1.57 \\
6.19 \\
0.62 \\
1.25 \\
0.64 \\
1.80\end{array}$ & $\begin{array}{l}1.40 \\
2.02 \\
1.75 \\
6.32 \\
2.34 \\
4.55 \\
5.13 \\
2.01 \\
5.70 \\
5.14 \\
4.21\end{array}$ & $\begin{array}{l}2.80 \\
3.10 \\
\\
1.76 \\
1.51 \\
5.41 \\
5.51 \\
7.33\end{array}$ & $\begin{array}{r}5.00 \\
4.25 \\
5.63 \\
7.41 \\
10.19 \\
5.95 \\
4.88 \\
4.60 \\
5.03 \\
4.86\end{array}$ & $\begin{array}{l}32.7 \\
19.4 \\
26.3 \\
22.7 \\
27.5 \\
31.5 \\
36.8 \\
28.4 \\
14.4 \\
25.6 \\
24.7\end{array}$ & $\begin{array}{r}9.2 \\
21.8 \\
15.1 \\
14.8 \\
31.8 \\
25.0 \\
32.0 \\
17.5\end{array}$ & $\begin{array}{l}80.1 \\
80.7 \\
79.1 \\
83.1 \\
83.1 \\
77.3 \\
80.5 \\
81.9 \\
81.6 \\
84.3\end{array}$ & $\begin{array}{l}66.4 \\
77.4 \\
78.0 \\
77.7 \\
78.4 \\
76.3 \\
79.5 \\
77.9 \\
77.0 \\
77.2 \\
77.9\end{array}$ & $\begin{array}{l}78.4 \\
83.8 \\
79.7 \\
80.9 \\
78.5 \\
71.4 \\
79.3 \\
73.1\end{array}$ \\
\hline \multirow[t]{2}{*}{$\begin{array}{l}\text { Mean } \\
\text { S.D. } \\
\text { p }\end{array}$} & $\begin{array}{l}2.10 \\
1.61\end{array}$ & $\begin{array}{r}3.68 \\
1.83 \\
>0.50\end{array}$ & $\begin{array}{r}3.52 \\
2.19 \\
>0.50\end{array}$ & $\begin{array}{l}5.78 \\
1.79\end{array}$ & $\begin{array}{r}264 \\
6.24 \\
<0.01\end{array}$ & $\begin{array}{r}209 \\
8.27 \\
<0.01\end{array}$ & $\begin{array}{r}81.2 \\
2.1\end{array}$ & $\begin{aligned} & 76.7 \\
& 3.51 \\
&<0.01\end{aligned}$ & $\begin{array}{c}78.1 \\
4.04 \\
<0.05\end{array}$ \\
\hline & \multicolumn{3}{|c|}{$\begin{array}{c}\text { Adult } \\
\text { dystrophy }\end{array}$} & \multicolumn{3}{|c|}{$\begin{array}{c}\text { Adult } \\
\text { dystrophy }\end{array}$} & \multicolumn{3}{|c|}{$\begin{array}{c}\text { Adult } \\
\text { dystrophy }\end{array}$} \\
\hline $\begin{array}{l}13 \\
14 \\
15 \\
16 \\
17 \\
18\end{array}$ & \multicolumn{3}{|c|}{$\begin{array}{r}1.80 \\
2.35 \\
0.69 \\
2.20 \\
10.35 \\
2.82\end{array}$} & \multicolumn{3}{|c|}{$\begin{array}{r}6.4 \\
4.7 \\
8.9 \\
16.6 \\
38.6 \\
13.7\end{array}$} & \multicolumn{3}{|c|}{$\begin{array}{l}80.2 \\
82.2 \\
83.0 \\
80.3 \\
76.9 \\
78.7\end{array}$} \\
\hline $\begin{array}{l}\text { Mean } \\
\text { S.D. } \\
\text { p }\end{array}$ & \multicolumn{3}{|c|}{$\begin{array}{r}3.36 \\
3.50 \\
<0.40\end{array}$} & \multicolumn{3}{|c|}{$\begin{array}{l}14.80 \\
12.40 \\
<0.05\end{array}$} & \multicolumn{3}{|c|}{$\begin{array}{r}80.20 \\
2.20 \\
<0.40\end{array}$} \\
\hline
\end{tabular}

the greatest reduction in muscle water content. The difference from normal control muscle water is significant statistically. Neurogenic atrophy showed a lesser reduction in muscle water content while adult dystrophy had essentially normal muscle water. The reduced water content in atrophic human muscle contrasts with the increase in muscle water reported in experimental muscular atrophy of animals (19).

An enzyme of particular interest in muscle is creatine kinase. Muscle is unique among tissues in its high content of creatine phosphate; hence, any change in creatine kinase would be pertinent. The mean enzyme content of all disease groups was decreased. The decrease in juvenile dystrophic and neurogenic muscle was of greater statistical significance (Table III).

In view of the importance of ATP in muscle metabolism, adenosine triphosphatase activity was examined even though its role in the complex reactions of intact muscle may be more involved than a direct hydrolytic cleavage of ATP. Adenosine triphosphatase activity was essentially normal in adult dystrophy but showed a reduction in juvenile dystrophy and neurogenic atrophy (Table III).

Succinic dehydrogenase (Table III) was measured as a representative enzyme of aerobic respiration. There was no change in enzyme activity in dystrophy. Secondary neurogenic atrophy showed a definite decrement but the small sample makes this result of questionable significance.

The most striking enzymatic alteration was the decrease in overall glycolytic activity in juvenile dystrophy. The reduction to approximately onethird control activity is a relatively greater reduction per unit of parenchymal tissue than that exhibited by the other enzymes studied. This reduction in glycolysis is in contrast to adult dystrophy, where the muscle shows a slight reduction based on wet weight, but does not vary significantly when the activity is based on noncollagenous nitrogen 
BIOCHEMICAL STUDY OF MUSCULAR DYSTROPHY

TABLE III

Enzyme activity of skeletal muscle

\begin{tabular}{|c|c|c|c|c|c|c|c|c|c|}
\hline \multirow[b]{2}{*}{ Subject } & \multicolumn{3}{|c|}{ Creatine kinase } & \multicolumn{3}{|c|}{ Adenosine triphosphatase } & \multicolumn{3}{|c|}{ Succinic dehydrogenase } \\
\hline & $\begin{array}{l}\text { Normal } \\
\text { controls }\end{array}$ & $\begin{array}{l}\text { Juvenile } \\
\text { dystrophy }\end{array}$ & $\begin{array}{l}\text { Neurog. } \\
\text { atrophy }\end{array}$ & $\begin{array}{l}\text { Normal } \\
\text { controls }\end{array}$ & $\begin{array}{l}\text { Juvenile } \\
\text { dystrophy }\end{array}$ & $\begin{array}{l}\text { Neurog. } \\
\text { atrophy }\end{array}$ & $\begin{array}{l}\text { Normal } \\
\text { controls }\end{array}$ & $\begin{array}{l}\text { Juvenile } \\
\text { dystrophy }\end{array}$ & $\begin{array}{l}\text { Neurog. } \\
\text { atrophy }\end{array}$ \\
\hline \multicolumn{10}{|c|}{ (Activity per mg. of noncollagenous nitrogen) } \\
\hline $\begin{array}{r}1 \\
2 \\
3 \\
4 \\
5 \\
6 \\
7 \\
8 \\
9 \\
10 \\
11 \\
12\end{array}$ & $\begin{array}{r}93 \\
75 \\
131 \\
119 \\
114 \\
100 \\
94 \\
80 \\
62 \\
98\end{array}$ & $\begin{array}{r}33 \\
68 \\
\\
37 \\
55 \\
76 \\
60 \\
66 \\
51 \\
78 \\
107 \\
51\end{array}$ & $\begin{array}{l}64 \\
73 \\
64 \\
48 \\
\\
48 \\
94 \\
36\end{array}$ & $\begin{array}{l}384 \\
225 \\
227 \\
326 \\
322 \\
423 \\
265 \\
304 \\
322\end{array}$ & $\begin{array}{l}291 \\
217 \\
\\
207 \\
240 \\
204 \\
294 \\
129 \\
344 \\
168 \\
202 \\
170\end{array}$ & $\begin{array}{r}114 \\
357 \\
285 \\
99 \\
\\
97 \\
112 \\
110\end{array}$ & $\begin{array}{l}128 \\
277 \\
228 \\
169 \\
216 \\
262 \\
281 \\
241 \\
169\end{array}$ & $\begin{array}{r}169 \\
245 \\
338 \\
42 \\
215 \\
242 \\
189\end{array}$ & $\begin{array}{l}145 \\
210\end{array}$ \\
\hline \multirow[t]{2}{*}{$\begin{array}{l}\text { Mean } \\
\text { S.D. } \\
\text { p }\end{array}$} & $\begin{array}{l}97 \\
20.98\end{array}$ & $\begin{array}{l}62 \\
20.71 \\
<0.01\end{array}$ & $\begin{array}{l}61 \\
19.20 \\
<0.01\end{array}$ & $\begin{array}{r}311 \\
66.1\end{array}$ & $\begin{array}{l}224 \\
63.5 \\
<0.01\end{array}$ & $\begin{array}{l}168 \\
36.1 \\
<0.01\end{array}$ & $\begin{array}{l}219 \\
55.72\end{array}$ & $\begin{array}{r}201 \\
71.92 \\
>0.50\end{array}$ & $\begin{array}{r}110 \\
82.34 \\
<0.02\end{array}$ \\
\hline & & $\begin{array}{l}\text { Adult } \\
\text { dystrophy }\end{array}$ & & & $\underset{\text { dystrophy }}{\text { Adult }}$ & & & $\begin{array}{l}\text { Adult } \\
\text { dystrophy }\end{array}$ & \\
\hline $\begin{array}{l}13 \\
14 \\
15 \\
16 \\
17 \\
18\end{array}$ & & $\begin{array}{r}106 \\
61 \\
68 \\
42 \\
92 \\
81\end{array}$ & & & $\begin{array}{r}425 \\
465 \\
290 \\
114 \\
197 \\
96\end{array}$ & & & $\begin{array}{r}37 \\
444 \\
285 \\
\\
37\end{array}$ & \\
\hline $\begin{array}{l}\text { Mean } \\
\text { S.D. } \\
\text { p }\end{array}$ & & $\begin{array}{l}75 \\
22.8 \\
>0.05\end{array}$ & & & $\begin{array}{l}264 \\
156 \\
>0.50\end{array}$ & & & $\begin{array}{l}201 \\
199.7 \\
>0.50\end{array}$ & \\
\hline
\end{tabular}

reference base. The decreased glycolysis in juvenile dystrophy is not specific since a similar proportional decrease was found in neurogenic atrophy.

One theory concerning the cause of muscular dystrophy implicates the contractile protein of muscle. Myosin, as the principal contractile protein component of the myofibril, was determined in an attempt to test this concept. Myosin determinations in normal control muscle show good agreement and the mean average of control values was $30.7 \mathrm{mg}$. of myosin- $\mathrm{N}$ per $100 \mathrm{mg}$. of noncollagenous nitrogen (Table IV). Both types of dystrophic muscle show a decrease in myosin content whether based on weight of wet muscle or on a parenchymal reference base of noncollagenous nitrogen. The muscle of adult dystrophy shows a greater decrease in myosin than juvenile dystrophy and the difference in myosin content based on noncollagenous nitrogen between adult and juvenile dystrophy is significant. Myosin content was not decreased in the neurogenic atrophy group.

\section{DISCUSSION}

The cause of human muscular dystrophy is unknown. Many theories for its etiology have been advanced. One recent concept, previously referred to, suggests that the contractile mechanism may be defective because of a failure in synthesis of proper quantities or qualities of myosin (20). A second suggestion is that the energy supply to the contractile fibril mechanism is faulty (21). In the latter case, the metabolic error may be attributed to some step or steps in the generation of high energy phosphate bonds which serve as the immediate source of energy for the muscle contraction of the myofibril.

In a consideration of the contractile function of muscle, the principal protein of the myofibril is myosin. It has been suggested that its concentration should bear an important quantitative relationship to the total mass of contractile pa- 
TABLE IV

Glycolytic activity and myosin content of voluntary muscle

\begin{tabular}{|c|c|c|c|c|c|c|c|c|c|c|c|c|}
\hline \multirow[b]{3}{*}{ Subject } & \multicolumn{6}{|c|}{ Myosin } & \multicolumn{6}{|c|}{ Glycolysis } \\
\hline & \multicolumn{3}{|c|}{$\begin{array}{l}\text { Mg. myosin per } \\
100 \text { mg. wet muscle }\end{array}$} & \multicolumn{3}{|c|}{$\begin{array}{l}\text { Mg. myosin } N \text { per } \\
100 \text { mg. noncollagen } N\end{array}$} & \multicolumn{6}{|c|}{$\begin{array}{l}\text { Activity units per } \\
00 \text { mg. wet muscle } 100 \mathrm{mg} \text {. noncollagen } \mathrm{N}\end{array}$} \\
\hline & $\begin{array}{l}\text { Normal } \\
\text { controls }\end{array}$ & $\begin{array}{c}\text { Juvenile } \\
\text { dys- } \\
\text { troph. }\end{array}$ & $\begin{array}{l}\text { Neurog. } \\
\text { atrophy }\end{array}$ & $\begin{array}{l}\text { Normal } \\
\text { controls }\end{array}$ & $\begin{array}{c}\text { Juvenile } \\
\text { dys- } \\
\text { troph. }\end{array}$ & $\begin{array}{l}\text { Neurog. } \\
\text { atrophy }\end{array}$ & $\begin{array}{l}\text { Normal } \\
\text { controls }\end{array}$ & $\begin{array}{c}\text { Juvenile } \\
\text { dys- } \\
\text { troph. }\end{array}$ & $\begin{array}{l}\text { Neurog. } \\
\text { atrophy }\end{array}$ & $\begin{array}{l}\text { Normal } \\
\text { controls }\end{array}$ & $\begin{array}{c}\text { Juvenile } \\
\text { dys- } \\
\text { troph. }\end{array}$ & $\begin{array}{l}\text { Neurog. } \\
\text { atrophy }\end{array}$ \\
\hline $\begin{array}{r}n o . \\
1 \\
2 \\
3 \\
4 \\
5 \\
6 \\
7 \\
8 \\
9 \\
10 \\
11 \\
12\end{array}$ & $\begin{array}{l}4.89 \\
3.92 \\
4.30 \\
2.95 \\
4.58 \\
3.40 \\
4.74 \\
4.09 \\
461 \\
4.47\end{array}$ & $\begin{array}{l}2.24 \\
4.01 \\
3.16 \\
3.28 \\
3.14 \\
2.76 \\
2.44 \\
2.51 \\
3.25 \\
3.68 \\
3.08 \\
2.91\end{array}$ & $\begin{array}{l}4.26 \\
3.60 \\
3.97 \\
4.29 \\
2.70 \\
3.36 \\
2.44 \\
224\end{array}$ & $\begin{array}{l}31.5 \\
28.3 \\
33.9 \\
25.3 \\
32.8 \\
30.9 \\
32.8 \\
31.8 \\
27.3 \\
32.2\end{array}$ & $\begin{array}{l}18.6 \\
28.4 \\
32.2 \\
26.6 \\
25.3 \\
25.0 \\
21.1 \\
30.7 \\
28.2 \\
30.5 \\
28.6 \\
24.6\end{array}$ & $\begin{array}{l}33.0 \\
32.4 \\
32.1 \\
31.3 \\
27.2 \\
26.4 \\
16.4 \\
191\end{array}$ & $\begin{array}{l}6,230 \\
7,130 \\
3,375 \\
3,730 \\
4,050 \\
3,100 \\
5,700 \\
5,730 \\
5,100 \\
6,100\end{array}$ & $\begin{array}{r}670 \\
2,040 \\
\\
1,363 \\
1,630 \\
1,300 \\
1,775 \\
1,300 \\
1,575 \\
1,350 \\
1,725 \\
1,560\end{array}$ & $\begin{array}{r}983 \\
1,870 \\
2,310 \\
1,300 \\
\\
670 \\
1,572 \\
960\end{array}$ & $\begin{array}{l}2,410 \\
3,100 \\
1,600 \\
1,930 \\
1,750 \\
1,695 \\
2,380 \\
2,680 \\
1,810 \\
2,640\end{array}$ & $\begin{array}{l}335 \\
867 \\
\\
665 \\
790 \\
710 \\
924 \\
955 \\
824 \\
675 \\
968 \\
976\end{array}$ & $\begin{array}{r}459 \\
1,010 \\
1,130 \\
570 \\
\\
318 \\
1,060 \\
492\end{array}$ \\
\hline \multirow[t]{2}{*}{$\begin{array}{l}\text { Mean } \\
\text { S.D. } \\
\text { p }\end{array}$} & $\begin{array}{l}4.20 \\
0.62\end{array}$ & $\begin{array}{r}3.04 \\
0.53 \\
<0.01\end{array}$ & $\begin{array}{r}3.38 \\
0.81 \\
<0.05\end{array}$ & $\begin{array}{r}30.7 \\
2.8\end{array}$ & $\begin{array}{c}26.7 \\
3.99 \\
<0.02\end{array}$ & $\begin{array}{c}27.2 \\
6.40 \\
>0.20\end{array}$ & $\begin{array}{l}5.024 \\
1,300\end{array}$ & $\begin{array}{r}1,481 \\
356 \\
<0.01\end{array}$ & $\begin{array}{r}1,380 \\
575 \\
<0.01\end{array}$ & $\begin{array}{r}2,200 \\
511\end{array}$ & $\begin{array}{r}790 \\
190 \\
<0.01\end{array}$ & $\begin{array}{r}719 \\
335 \\
<0.01\end{array}$ \\
\hline & \multicolumn{3}{|c|}{$\begin{array}{l}\text { Adult } \\
\text { dystrophy }\end{array}$} & \multicolumn{3}{|c|}{$\underset{\text { dystrophy }}{\text { Adult }}$} & \multicolumn{3}{|c|}{$\underset{\text { dystrophy }}{\text { Adult }}$} & \multicolumn{3}{|c|}{$\underset{\text { dystrophy }}{\text { Adult }}$} \\
\hline $\begin{array}{l}13 \\
14 \\
15 \\
16 \\
17 \\
18\end{array}$ & \multicolumn{3}{|c|}{$\begin{array}{l}3.96 \\
3.21 \\
3.92 \\
3.49 \\
0.81 \\
2.48\end{array}$} & \multicolumn{3}{|c|}{$\begin{array}{l}26.4 \\
27.2 \\
19.6 \\
15.6 \\
11.3 \\
13.1\end{array}$} & \multicolumn{3}{|c|}{$\begin{array}{r}7,150 \\
4,100 \\
3,980 \\
5,900 \\
720 \\
4,225\end{array}$} & \multicolumn{3}{|c|}{$\begin{array}{r}2,900 \\
2,090 \\
1,900 \\
2,650 \\
605 \\
2,218\end{array}$} \\
\hline $\begin{array}{l}\text { Mean } \\
\text { S.D. } \\
\text { p }\end{array}$ & \multicolumn{3}{|c|}{$\begin{array}{r}2.97 \\
1.10 \\
<0.02\end{array}$} & \multicolumn{3}{|c|}{$\begin{array}{r}18.86 \\
6.60 \\
<0.01\end{array}$} & \multicolumn{3}{|c|}{$\begin{array}{r}4,350 \\
2,170 \\
>0.40\end{array}$} & \multicolumn{3}{|c|}{$\begin{array}{r}2,060 \\
802 \\
>0.50\end{array}$} \\
\hline
\end{tabular}

renchymal tissue (11). If the metabolic fault in muscular dystrophy is in the contractile element of the myofibril, a disproportionate quantitative decrease in myosin content in comparison to other parenchymal muscle constituents, such as the enzyme systems involved in the transfer and production of high energy phosphate, might occur. The experiments indicate that myosin is reduced. However, the average reduction in myosin content is markedly less than that of glycolytic activity and slightly less than the reduction in creatine kinase and ATP-ase activity in the group of patients termed "juvenile dystrophy." Although the decrease in myosin content of dystrophic muscle is only moderate in degree, the possibility of a more significant qualitative alteration cannot be ruled out by these experiments.

In human muscular dystrophy, the only previously reported metabolic alterations in enzyme activity have been decreases in overall glycogenolysis and in some individual enzymes of this system, including phosphorylase, phosphoglucomutase and aldolase $(22,23)$. The results reported in this paper confirm the absolute decrease of glycolysis in muscular dystrophy but limit this alteration to cases classified here as juvenile dystrophy. The percentile decrease in muscle glycolytic activity to one-third normal activity is in close agreement with the results of Schapira, Dreyfus, Schapira and Kruh (23). The reduction in glycolysis is considerably greater than the absolute decrease of myosin content, adenosine triphosphatase, or creatine kinase activity. The severe glycolytic alteration in juvenile dystrophics, with only moderate muscle weakness, points to the possible magnitude of the metabolic derangement of muscle in patients with advanced muscle wasting. The role of lactic acid production in energy generation by muscle in states of relative anoxia is well known. Recent experimental evidence suggests that lactate 
production may also be significant in the resting state (24). The role of glycolysis in human skeletal muscle metabolism may be of greater importance than has been believed in the past.

All enzyme systems tested including glycolysis are well preserved in the adult with dystrophy. This is particularly impressive when contrasted with the loss of enzyme activity in the juvenile dystrophic. This may represent merely a quantitative difference in disease severity between the two groups. However, the disproportionate decrease in myosin in the adult dystrophic in the face of well maintained enzymatic activity suggests that there may be a different metabolic defect in the two groups.

Dreyfus, Schapira and Schapira (22) speculate whether the muscle weakness in muscular dystrophy is due to enzymatic defects in glycolysis or whether these alterations in metabolism are the sequelae of a more primary biochemical flaw. This present study confirms the decrease in glycolytic activity, but also indicates that there is a significant reduction in myosin concentration and in nonglycolytic enzyme systems involved in high energy phosphate transfer. This indicates that the metabolic deficit in muscular dystrophy is more widespread than suggested by the work of Dreyfus and associates. The present data suggest that the biochemical alterations in dystrophy are complex and involve both myofibrillar and sarcoplasmic components. The disproportionate reduction in activity of the glycolytic system in human dystrophy suggests that further study of the individual components of this system in human dystrophy might be rewarding.

In general, similar quantitative alterations in enzyme activity are found in neurogenic atrophy and juvenile muscular dystrophy. Therefore, none of the changes are specific for the skeletal muscle weakness in muscular dystrophy. The similarity in metabolic alterations in myogenic and neurogenic muscle disease is susceptible to various alternative theories. A common enzyme or cofactor deficiency may lead to the failure of adequate lactic acid production in both types of disease or a stereotyped deficit may result from fundamentally different metabolic errors.

Another possible explanation is that as a result of disease there is an alteration in muscle mem- brane permeability. It has been demonstrated that the intracellular enzyme, aldolase, diffuses more rapidly from dystrophic mouse muscle than from normal muscle (25). The low content of intracellular muscle enzymes in human dystrophy could be explained by this mechanism. A similar nonspecific alteration of muscle membrane permeability could occur in neurogenic muscle atrophy. The normal serum aldolase in neurogenic disease of muscle is, however, somewhat against this theory (26).

A continuing problem in assessing the degree of skeletal muscle involvement in myopathy is the factor of tissue heterogeneity. Histologic preparations suffer from the handicap that individual microscopic sections may show widely disparate pictures. It is often difficult for the pathologist to give more than a semiquantitative evaluation of the extent of muscle disease. Quantitative chemical determination of skeletal muscle constituents, in which both the functional and replacement elements of muscle are measured, may aid in the clinical evaluation of muscle disease. These values, which are based on aliquots taken from several grams of homogenized tissue, are probably more representative of overall mean tissue composition in a given muscle than are the individual histologic sections which represent only a few milligrams of muscle tissue. It has been reported that the fat content of diseased dystrophic muscle may vary by 50 per cent in two different areas (11). Quantitative fat determinations in the group of patients reported in this paper, who have only moderate muscle involvement, vary within a relatively small range. The past reports of marked differences and overall increase in the fat content of dystrophic muscle may well reflect the long duration of the disease process (17) rather than a fundamental alteration of fat metabolism or accelerated lipid deposition in dystrophic muscle. It would appear that in early muscle disease the extent of fat deposition in muscle tissue has no diagnostic significance and, indeed, shows no significant increase over normal control muscle. It seems unwise, therefore, to interpret fat replacement of muscle as indicating a specific metabolic fat defect in muscular dystrophy.

Conversely, a significant increase in the fibrous tissue content of muscle is an early finding in ju- 
venile muscular dystrophy. This would seem to be a more dependable indication of early muscle dysfunction in this disease than an increase in muscle fat.

\section{SUMMARY}

1. The content of myosin, creatine kinase, adenosine triphosphatase, succinic dehydrogenase, overall glycolysis, fat, collagen and water in the skeletal muscle of patients with muscular dystrophy has been determined. This has been compared with skeletal muscle analysis in normal controls and neurogenic atrophy.

2. The collagen content of juvenile dystrophic and neurogenic atrophy muscle was increased. The water content of muscle in these two patient groups was reduced slightly. Muscle fat was not significantly altered in any patient group.

3. In juvenile and adult dystrophy, the myosin content related to noncollagenous nitrogen was reduced.

4. Glycolysis showed the most striking decrease of the parenchymal tissue elements tested. This was reduced to one-third of normal in juvenile dystrophy. Since a similar reduction was found in neurogenic atrophy, this is not the specific metabolic derangement in dystrophy.

5. Adenosine triphosphatase and creatine kinase activity were reduced in both juvenile dystrophy and neurogenic atrophy.

6. The muscle of adult dystrophy showed no enzyme alterations although the myosin content was reduced to a greater extent than in the other two patient groups.

\section{REFERENCES}

1. Michelson, A. M., Russell, E. S., and Pinckney, J. H. Dystrophica muscularis: A hereditary primary myopathy in the house mouse. Proc. nat. Acad. Sci. (Wash.) 1955, 41, 1079.

2. Walton, J. N., Race, R. R., and Philip, U. On the inheritance of muscular dystrophy. Ann. hum. Gen. 1955, 20, 1.

3. Tyler, F. H., and Stephens, F. E. Studies in disorders of muscle: IV. Clinical manifestations and inheritance of childhood progressive muscular dystrophy. Ann. intern Med. 1951, 35, 169, 1164.

4. Archibald, K. L., and Vignos, P. J. Study of contractures in muscular dystrophy. Arch. phys. Med. In press.
5. Swinyard, C. A., Deaver, G. G., and Greenspan, L. Gradients of functional ability of importance in rehabilitation of patients with progressive muscular and neuromuscular diseases. Arch. phys. Med. 1957, 38, 574.

6. Gonnella, C., Harmon, G., and Jacobs, M. The role of the physical therapist in the gamma globulin poliomyelitis prevention study. Phys. Ther. Rev. 1953, 33, 337.

7. Hasselbach, W., and Schneider, G. Der L-Myosinund Aktingehalt des Kaninchenmuskels. Biochem. Z. 1951, 321, 462.

8. Lowry, O. H., Gilligan, D. R., and Katersky, E. M. The determination of collagen and elastin in tissues, with results obtained in various normal tissues from different species. J. biol. Chem. 1941, 139, 795.

9. Folch, J., Ascoli, I., Lees, M., Meath, J. A., and LeBaron, F. N. Preparation of lipide extracts from brain tissue. J. biol. Chem. 1951, 191, 833.

10. Folch, J., Lees, M., and Sloane-Stanley, G. H. A simple method for preparation of total pure lipide extracts from brain. Fed. Proc. 1954, 13, 209.

11. Hoagland, C. L. Some biochemical problems posed by a disease of muscle in Currents in Biochemical Research, D. E. Green, Ed. New York, Interscience Publishers, Inc., 1946, p. 413.

12. Lilienthal, J. L., Jr., Zierler, K. L., Folk, B. P., Buka, R., and Riley, M. J. A reference base and system for analysis of muscle constituents. J. biol. Chem. 1950, 182, 501.

13. Schneider, W. C., and Potter, V. R. The assay of animal tissues for respiratory enzymes. II. Succinic dehydrogenase and cytochrome oxidase. J. biol. Chem. 1943, 149, 217.

14. Cantoni, G. L., and Vignos, P. J., Jr. Enzymatic mechanism of creatine synthesis. J. biol. Chem. 1954, 209, 647.

15. DuBois, K. P., and Potter, V. R. The assay of animal tissues for respiratory enzymes. III. Adenosine triphosphatase. J. biol. Chem. 1943, 150,185

16. LePage, G. A. Glycolysis in tumor homogenates. J. biol. Chem. 1948, 176, 1009.

17. Adams, R. D., Denny-Brown, D., and Pearson, C. M. Diseases of Muscle. New York, Paul B. Holber, Inc., 1953, p. 260.

18. Barnes, B. A., Gordon, E. B., and Cope, O. Skeletal muscle analyses in health and in certain metabolic disorders. I. The method of analysis and the values in normal muscle. J. clin. Invest. 1957, 37, 1239.

19. Humoller, F. L., Griswold, R., and McIntyre, A. R. Comparative chemical studies in skeletal muscle following neurotomy and tenotomy. Amer. J. Physiol. 1950, 161, 906.

20. Zierler, K. L. Alpha-tocopheryl phosphate and energy transfer in muscle in Proc. First and Second 
Medical Conference of Muscular Dystrophy Association, New York, 1951-52, p. 108.

21. Fenn, W. O. Recent advances in basic muscle chemistry, physiology, and pharmacology. Amer. J. phys. Med. 1955, 34, 8.

22. Dreyfus, J. C., Schapira, G., and Schapira, F. Biochemical study of muscle in progressive muscular dystrophy. J. clin. Invest. 1954, 33, 794.

23. Schapira, G., Dreyfus, J. C., Schapira, F., and Kruh, J. Glycogenolytic enzymes in human progressive muscular dystrophy. Amer. J. phys. Med. 1955, 34, 313.

24. Andres, R., Caden, G., and Zierler, K. L. Metabolic exchange of human muscle in situ. Amer. $\mathrm{J}$. phys. Med. 1955, 34, 286.

25. Zierler, K. L. Aldolase leak from muscle of mice with hereditary musclar dystrophy. Bull. Johns Hopk. Hosp. 1958, 102, 17.

26. Thompson, R. A., and Vignos, P. J. Serum aldolase in muscle disease. Arch. intern. Med. In press.

\section{CORRECTION}

Footnote 1 to the article by Hoffman and Rowe, entitled "Some Factors Affecting Indicator Dilution Curves in the Presence and Absence of Valvular Incompetence," which appeared on page 138, volume 38, 1959, should read as follows: "Material supplementary to this article has been deposited as Document Number 5897 with the ADI Auxiliary Publications Project, Photoduplication Service, Library of Congress, Washington 25, D. C. A copy may be secured by citing the Document Number and by remitting $\$ 1.25$ for photoprints or $35 \mathrm{~mm}$. microfilm. Advance payment is required. Make checks or money orders payable to: Chief, Photoduplication Service, Library of Congress." 